\title{
Collaborating and Co-operating to Make the Connection: How Law Librarians and Academics Can Work Together to Develop Communities of Legal Practice
}

\begin{abstract}
The Library is of value as a physical and social space, as a place that can facilitate learning; independently and in distinct ways to its role as repository of, and point of access to, information. The problems that defenders of this "learning place" aspect of the Library face are bound up with a very powerful, and indeed prevalent, metaphor. This metaphor is of teaching and learning as the transfer of information from one place or head, to another place or head. Therefore, Graham Ferris and Angela Donaldson put forward a far more realistic account of learning, and combine it with an example of learning being enacted in practice. We need to articulate the value of the Library as a place of learning because it is under threat from pressures on resources that are being deployed on a "common sense" but fallacious assumption that Libraries are about the storage and manipulation of information only.
\end{abstract}

Keywords: libraries; education

\section{INTRODUCTION}

Famously, if ambiguously, Wittgenscein wrote:! "What we cannot speak about we must pass over in silence." If we read this as a simple matter of what it is possible to say, then it identifies a problem for anyone who wishes to defend something they feel is of value, but who cannot find words to articulate the basis of the feeling, and turn 
it into an effective argument The importance and value of tacit knowledge, of knowledge that is not readily expressible in general propositions, is widely recognised. ${ }^{2}$ However in the decision making of organisations, that which cannot be stated, and which therefore cannot be measured even through a proxy measure, will not be given much weight.

That the Library is a valuable place of learning is obscured by a metaphor based on a somewhat outdated but still powerful view of education as a process of transmission of ideas or information from someone who knows to someone who is ignorant. "Transmission" is a verb that requires a package of some sort to transmic, and the obvious contemporary way to imagine this package is as "information". Information is obvious (as opposed to ideas, or understanding, or character which were obvious in the pasc) because information transfer is itself a key metaphor in discussions of "Information Technology". So, this metaphor forms part of a coherent system of metaphors, that together form a "common sense" way to understand learning. ${ }^{3}$

The metaphors we use are not inconsequential. It has been persuasively argued that they:" "structure how we perceive, how we think, and what we do." We are not arguing that one can avoid the use of metaphor, and especially in discussions of novel human activity such as produced by advances in computer science, as Lyman pointed out: 5

"... the Article 2B debate, like all discussion of "the computer revolution" has become trapped in its own meaphors - metaphors about "information highways" and the "knowledge economy." The first stage of every process of hiscorical change must necessarily use metaphors from the past, but they are at best heuristic."

Our only criticism of this is the implicit assumption that a mature domain can avoid the use of metaphors. However, the risk of distortions and blind spots produced by over-reliance on the information transmission metaphor imperils realistic understanding of learning and recognition of aspects of Libraries not easily visible from such a perspective.

One reason the value of the Library as a place of learning is difficult to articulate and explain is because it relies upon a different understanding of learning; one that is not so dominated by the metaphor of information transmission. Therefore we need to explore this alceraam tive undersarding of learning in order to articulate our arguments about the Library.

\section{SITUATED LEARNING}

To avoid any doubt, we recognise the importance of information, in the form of words or diagrams or images, in legal education. Law is a highly textual subject and legal practice is concerned with words, rules, and compliance with articulated processes. Indeed, it is hard to think of anyone who is engaged in legal education that would disagree. The issue is not whether this type of knowledge is important but what else is important in legal education. As Seely Brown and Duguid pointed out there is a risk of only seeing information when designing institutions and practices: 6
"Ignoring the clues that lie beyond information ... leads to a world of what we think of as tunnel design - a kind of purblind design of which, in the end. we are all victims. In this world we are often expected to live on a strict information only diet. Indeed, it's a world that usually addresses worries about information by simply offering more. Yet when only information is on offer, more often means less."

Hence, although it might seem too obvious to need statement, we do need to start with what is obvious but obscured by prevalent metaphors. It is not minds, or heads, that learn things; learning is not disembodied but is the activity of a person.?

The metaphor of information transfer rather obscures the fact of the body, and sharply focusses on the "information" that is being "moved". However, the learner is not a warehouse for information stuff, and the vital processes for effective learning are the perception or construction of meaning by the learner. For better or worse we know that learners do not respond to attempts at information transfer by acting as retencive recipients and reproducers of information. Information changes in "transmission" and factors that are obscured by the transmission metaphor colour what is "received" by learners. Where, physically and socially, a learner hears, reads, talks or writes about a topic impacts upon where in the future the topic is relevant for the learner. Relevance is what makes information available in the future. This is why, in our own experience, universicy students cell us they have forgotten what they learnt in the first year by the third year, although they may express it as their never having been taught the same.

One illustrative example from educational research brings home the importance of this embodied, and specific to learning contexc, aspect of learning. It is powerfully telling because it concerns very successful and talented learners - the issue is not one of students who need to do better - the issue is of an approach to learning that needs to be at least supplemented, if not rejected outright as simply misleading. Engineering students were asked about the forces that operate when a coin has been flipped (as when calling heads or cails). They had all been taught Newtonian theory, which tells us only one force is in play (gravity), and no doubt could and did produce thac answer in assessment. What they answered, using diagrams and not a typical physics answer calling for formulae, was two forces were in conflict: gravity (pulling down) and momentum (pushing up). This answer has respectable 
historical antecedents (it is basically Aristotelian), but has been known to be wrong since Newton, a fact all physics graduates know (in a test situation). ${ }^{8}$

Such research, and it is not an isolated finding, ${ }^{9}$ confirms the importance of non-official-curricula factors in what is going on when people learn. The phenomenon has been described as situated learning: ${ }^{10}$ where, and with whom, one learns will impact upon what is learned, and that impact may be more significant than the formally recognised teaching activities taking place. The researchers who took this insight most seriously, and developed it into a novel account of learning, were Jean Lave and Etienne Wenger." Happily they were not concerned with schooling or children as learners, their work drew heavily upon Lave's work with apprentice tailors, and other nonschool situated learning. ${ }^{12}$ Thus, it applies to adult learners and learning in the workplace with at least as much force as it applies to a school environment. The key linked ideas Lave and Wenger developed were: legitimate peripheral participation. Where a learner was in a situation in which she was engaged in legitimate peripheral participation over time then that learner almost always leant what she needed to become a competent practitioner. This is not to suggest there is no need for curriculum or content or reflective learning in Higher Education or workplace learning and teaching, it is to argue that those elements are not sufficient for effective learning.

It is not always possible to provide opportunities for legitimate peripheral participation in university or the work place. Sometimes the learner has gone beyond the realm of apprentice learner, and is now involved in expert participation that is at the vital centre of the discipline. Obviously, such a learner needs to be supported in different ways to the neophyte. Often, the separation of teaching and learning from the places in which the discipline is practised makes it difficult to support an ideal learning environment; although clinical legal education and work placed pupillage or training contracts are valued features of preparation for the legal professions. ${ }^{13}$ However, even outside clinical education and work based learning we can still try to maximise those elements of a good learning environment that can be made available - if we are aware of what we are aiming to achieve. Too often talk of information, content, subject matter, or information resources drowns out discussions of the vital elements for learning Lave and Wenger identified. Thus, it is important to consider what the elements that situated learning identifies as leading to successul jearning mean.

"Legitimate" means something like "permission" but aiso something like "member". In effect the idea has two aspects: it is bestowed by practitioners upon apprentices, it is the grant of access; and, it is joining the group of practitioners, it is a shift in identity, one becomes a student, trainee, newly qualified solicitor. Thus one aspect is external (permission) and the other is internal (membership) to the learner. Legal professional education and training tends to split the two aspects sequentially: one becomes a student of law (permission); then upon successful study one is admitted into the practice arena (marked by entry into professional body and work based learning). Obviously reality is more complex than this schematic. The university live clienc law climic makes a student into a practitioner, as the student can experience providing legal services; the application for membership of the Law Sacjety or an Inn of Court involves the grant of permission, and may be denied if the applicant has a history of dishonesty: mere completion of a Graduate Diploma or Qualifying Law Degree does not entitle a student to membership.

Ic is important to note that legitimate access is not merely tolerance of presence, and thac legitimate access to the area of practice is not of benefit to the learner alone. The discipline reproduces itself through the reception of learners; today's learners are the practitioners of tomorrow. Legitimacy is a feature both of learning and of the reproduction of the group. Concrol over legitimate access to practice is how the communicy of practice, or regulator of the practice community, controls the composition of the "community of practice" or "profession". 14 Legitimate access to a community of practice makes identification of the practice the community is engaged in an important question. We take this up in our consideration of participation.

\begin{abstract}
"Participation" is at one level of consideration participation in a specific community of practice, being part of a social group engaged in various activities. $^{15}$ However, a community of practice takes its group identity, and provides an identity to its members, through the practice in which it is engaged. ${ }^{16}$ Therefore, participation has at least two reference groups: participation in the actual community of practice; and participation in the practice that that community is engaged with as are many other communities of practice. We will call a community of practice "community"; and a set of communities engaged in the same practice a "network"; 17 and use the term "group" as a general term thas can cover either communities or networks.
\end{abstract}

In legal education there will be more than two potential reference groups, because "egal practice" is made up of many pracices. So, one might be a legal academic and form part of a community of educational practice in s. $^{3}$ Law School, and thus connerted to a network of Law Schools engaged in legal educacion; but also a property lawyer, and as such part of a smaller community of educational practice of property lawyers at the Law School, connected to a national or international network of property lawyers engaged in research and scholarship concerned with property law. Alternatively, one might be engaged in prosecution of criminals, and part of a community located in an office of the Crown Prosecution Service, and associated with a network of prosecutors. 
A community of practice is small, it will be limited to those one has regular contact with. A network can be very large and extend across time and space. A network of communities engaged in the same practice can give rise to an imagined community of practitioners. An imagined community is imagined in the same sense that a nation is imagined, or a religious community is imagined: ${ }^{18}$

"It is imagined because the members of even the smallest nation will never know most of cheir fellow-members, meet them, or even hear of them, yet in the minds of each lives the image of their communion."

In the same way the solicitors profession is an imagined community. Such imagined communities can be very important for real communities and individuals, as Anderson pointed out people have been and are willing to risk death for their Nation.

Business organisations, such as firms or chambers, will be the site for communities, but networks will not tend to respect organisational boundaries, and communjties of practice may include members whose primary network idencification vary. Thus, what one participates in when one has access to legitimate participation is not a simple matter or unitary in meaning, and this can have important consequences for learning, whether in educational institutions or business organisations. Participation means being a part of the activity the community is engaged in. The community will through its activities define just what that means, but the community is linked into networks of practice, imagined communities of practice, and organisations. The community has to negociate the practice and its meaning within this context, and subject to the influence of networks, imagined communities, and organisations.

in conclusion, and to try and give a useable summary of this idea of participation, let us consider an undergraduate student on an LLB. The law undergraduate has peers and interacts with tutors; these form a community. This community is engaged in some practice or practices, but it is probably not engaged in professional legal practice (unless the student is involved in a live client clinic, or similar experiential learning). The community is invo'ved in an educational practice: but that might just be meeting the assessment demands of the course (teaching to the test); or it might involve legal research as a practice - one that the student is a neophyce in and the tutor is a master of $o^{\circ}$ it might involve engagement in finding meaning through the construction of stories of the law: or legal practics, or legal research ${ }^{19}$ These practices may, or may not. be understood by the student to link up with networks of academic or professional legal practices. The student may, or may not, join an imagined community of lawyers, or of those concerned with justice through law.

"Peripheral" is a spatial metaphor and it indicates not central or vital. The neophyte is protected from making costly mistakes. ${ }^{20}$ Recognition of competence is withheld until the neophyte has demonstrated mastery of the necessary parts required for competent practice. As the new member becomes experienced and skilled in the talk and activity of the community of practice she moves from the periphery towards the centre of the social space occupied by the community.

An idea of a periphery and a centre brings with it an idea of a boundary of the community. People and objects may cross the boundaries of communities. Books or documents can be boundary objects that have meaning in several communities and play an imporcant role in forming or shaping networks and imagined communities.

The model of learning encapsulated in the phrase "legitimate peripheral participation" is very dissimilar to the more familiar, and often unconsciously assumed, model of information transmission. There may be no-one who has the expressible knowledge to transmit. Learners learn through the opportunities for observation given by legitimate presence, and the licence this gives them to ask questions, and by trying to engage in the practice they have observed. At first the participation is peripheral, the learners are not relied upon, and not allowed to experiment early on with activities that cause serious damage when done incompetently. As they gain in practice ability, learners move towards the centre of the community of practice and become a learning resource for newer learners. Learners learn how to do, and how to talk about doing. Learners do not stop learning, and as they become central members of the community they may change what there is to know. Novel stories may become new knowledge and understanding, if they are endorsed and accepted by the community of practice. Indeed such new knowledge may then inform networks and imagined communities. ${ }^{21}$

So if we drop the assumption that everything of importance is happening in a disembodied reified cognitive arena. and return learning to people in places doing things and talking, how might this change our understanding of the Library? Let's get physical.

\section{LIBRARY AS A PLACE WHERE BOOKS ARE}

It is worth focussing on one major element of the Law Library: the collections of reporis, encyclopaedias, and bound journals. It is clear that a book is not merely a repository of the information it contains, and that a long historical series of books is not merely a lot of books across which the information is contained. Seely Brown and Duguid list several important features of physical books that are not easily carried over into information available through a computer screen, or mobile phone screen, or a print-out. ${ }^{22}$ 
One set of features, and an area where the now common pdf of excerpts from printed books does help a lot, is the information contained in the formatting and organisation of the words on the page. An ICLR report is full of information given peripherally to an experienced reader, and available to a neophyte reader. The first page of a report will have the name of the case; the Court; the members of the bench who heard the case; the dates of the hearing, and the year of the judgment, and year of the report (which may differ). Then there are the key words that indicate the subject matter of the case in italic font. Below them is the headnote, an account of the facts and issue, then, following the word "held" a summary of the judgment reached and the Court's reasoning. The headnote may continue beyond the start page, but as we all know it is a truly wonderful resource. Ic takes a very short time for an experienced user to extract a wealth of information, and decide whether it is useful or necessary to proceed to read the judgments.

Even with the now widely available pdf (which piggybacks on the printed work) a neophyte who relies upon a source other than the book loses out on information. If too smail a screen is used to access an electronic copy of a report then the risk of confusion is great, the very clear formatting can become obscure. Students do not always use the pdf, and the html text version of the Reports are far more difficult to visually scan, meaning that the qualities identified above are lost.

Any database that catalogues by case report misses out the information carried by place in the Reports - It is quite easy to misunderstand the relationship between Barciays Bank $v$ O'Brien and CIBC v Pitt if one downloads just one of the reports (typically the O'Brien case); yet only when the reports are read together can one understand the law (they are reported sequentially at p. 180 and p. 200 in the Appeal Cases). ${ }^{23}$ Finally, the book carries a contents page, and can be skim-read (due to the excellent design of the reports noted above) in a way that the databases cannot be. The format of the book is a very informative aspect of the report, and computer mediation tends to obscure these valuable qualities.

Digital information media handle some types of information superbly, but they are efficient partially by excluding information unsuitable for digitisation; a lot of information present in the physical and sociai world is simply lost in translation to digital form. The Repors are impressive; regular bound copies running for years, decades, across centuries. They are the repository of the law, the physical embodiment of a practice that has been continuous if not corsistent over a long period of time. The Law Reports are a physical warrant of the import. ance of their contents. There are visually distinct series and sub-series of Reports. The status of the reported decisions of the Courts is of course a vital fact about law to grasp, and a difficult one for many. The Reports in their physical solidity, muced but clear self-important actuality can carry this message. If student identification with an imagined community, or imagined communities, is a desired outcome, then the physical reports naturally embody and express elements conducive to such imagining. ${ }^{24}$

The committed and technically sarvy employee of a NGO's blog may create something that looks more impressive than the online report; the Company website is likely to be more interesting and interactive than the legal database; the publisher hosted materials may be far more attractive than the Government legislation website. Yet these are false indicators of worth, that reflect the low costs for talented IT users of good design, and the high price business puts on its external image. In the Library the most important books are given pride of place and are most impressive. Indeed only a deliberate attempt to falsify the record could remove the relevant strengths of tradition across sources.

It is not only the Law Reports that manifest the importance of and longevity of sources. The legal encyclopaedias are impressive series of books. A long run of bound copies of the Law Quarterly Review brings home the extent of the academic tradition of legal study. The quality of the works, their extent and continuation over long periods of time are all aspects of their warrant for the importance of their contents. One can, and people and businesses do, fake tradition, authority and importance on the internet. It is far more difficult to do so in the physical world, and impossibie to do so in a properly run Library. These marks of authority and authenticity are important ones for anyone who is new to law and legal practice.

Books as objects have individual histories. This can create problems for Librarians, as annotation is often unwelcome. However, there may be some positive aspects of the physical history of a book. One can see which cases are the most heavily used, and that the headnote is the most heavily used part of the Reporr ${ }^{25}$ However it is more the imagined history of the book that is likely to be significant for a learner. Reports, or collections of Statutes; and policy or Law Commission documents, or travaux preparatoires; and authoritative commentaries, academic commentaries, precedent books. academic or professional monographs, and scudent text books, are all physica! objectifications of textually linked communities that have spanned time and space. In a similar but distinct way, the physical history of the collection enables and can naturally lead to a user feeling part of an imagined community of scholaris or practitioners' communities imagined across time ${ }^{26}$

Finally. books have the dual qualities of being "immur. able mobiles", easily moveable through space and yec resistant to change. ${ }^{27}$ Where the internet is constantly changeable and in flux, the book is relatively difficult to change, and any attempts at change are usually readily apparenc. This makes books, and other physical documents, potentially very useful as "boundary objects". The idea behind the boundary object is that it travels across the boundaries of communities, thereby linking networks 
together, or integrating communities with organisational imperatives. Wenger gives the example of the claims forms that the claims processors he studied filled in and passed on within their organisation. ${ }^{28}$ The nautical chart is another example of a physical document that embodies knowledge, and links networks, has organisational importance, and coordinates a community of practice. ${ }^{29}$ The ICLR Law Report is an authoritative text that coordinates the community of praccice formed by a trial process. It travels across networks, linking solicitors, barristers, academics and students. It is able to do this because of its fixity of form. ${ }^{30}$ The book does not change its content between occasions of access. Although the book is mobile its content is immutable, hence its utility as a boundary object. In law the reliability of precise reference across practitioners and over time, the primacy of the legal source in canonical form, is a central aspect of the domain.

Hopefully, all of this is familiar. if not usually given prominence in discussions of the Library as a learning resource. Next we draw on our experience at Nottingham Trent to illustrate how putting learners into the Library can facilitate learning and the formation of identity as members of a legal community.

\section{THE GRADUATE DIPLOMA IN LAW}

Angela used a situated learning approach to teach basic legal research skills to the Graduate Diploma in Law (GDL) students, as part of the English Legal Method (ELM) module. GDL students are graduates in non-law subjects undertaking a year-long law conversion course. Most GDL students then go on to complete either the one year Legal Practice Course or the Bar Professional Training Course. Compared with undergraduate law students GDL students are generally older, obviously graduates, and have made a conscious decision to convert to law after successfully completing a first undergraduate degree. The reality of that choice is that they have already deferred entry into the job market for three years, and intend to spend a further two years in education. Most of them are carrying a financial debt from their undergraduate study, and will increase that debt by signing up to two further years of study. No doubt they hope that after their five years of Higher Education they will have a chance of embarking upon a personally and financially rewarding career in law. GDL studenus are generally very focused studens; keen to learn, keen to engage, and happy to ask questions.

EL.M for GDL students is delivered as an intensive 6 week module, before the scudents move on to study the other qualifying law subjects. As the GDL students are new to the subject of law, the ELM module acts as their introduction to the fundamentals of law, the legal system, and basic legal concepts. Specifically the course introduces: the court system and mechanisms for alternative dispute resolution; the legal professions; case law, and the doctrine of precedent; and statute law.
The Law Librarian plays a key role in the ELM teaching team, delivering an introductory lecture on primary and secondary sources of law and the texts that embody them. To make these texts real for the students the Law Librarian runs several small group sessions, introducing both printed and electronic legal resources, and devising activities for the students to engage in that require the use of both printed and electronic resources.

As noted above the role of the Law Librarian goes beyond delivery of teaching designed by academics, and in 2010 Angela introduced princed legal research skills sessions for the GDL students, as part of their ELM module. The GDL is the only programme to have this training embedded within the curriculum. The main reason that such training is not embedded within other programmes is because of the numbers concerned. NTU has an average GDL cohort size of 80 , which means that it is possible to deliver practical, hands-on skills training in tutorial groups. This would not be possible to replicate on the undergraduate law degree programmes, where NTU has an annual average first-year intake of 560 . However, in order to give LLB and other postgraduate students, such as LLM or even PhD students, the opportunity to improve their printed legal research skills the same session forms part of the Library's Events for Students programme, which students can sign up to attend.

During the sessions the students get to physically handle the Current Law Case Citators, and Yearbooks, law reports indexes, various law reports, Halsbury's Laws, and Halsbury's Statutes. The physical contact takes place within the law collection of the Library, and is required in order to complete relatively simple legal research tasks: such as locating an Act, locating an entry in Halsbury's Laws, or looking up a case in the Current Law Yearbook. It should also be noted that this is one of the first subject-related group sessions that the students have. Therefore, it also enables them to get to know the other scuderts in their tutor group, in a more relaxed setring than formal classes, and surrounded by the paraphernalia of legal research.

If GDL students are trying to form a sense of their new identity as law students, who hope to become law practitioners, then the Library and the law books offer a setting primed to facilitate the imagination of those communities the GDL students are joining. ${ }^{31}$ Their research tasks are peripheral participation in a community of praccice, lirked to a network of practice, both of which demand familiarity with primary source texts, and aware ness of the authority of primary sources, as an assumed part of the world. The GDL students have cecided they want to be part of the student community of practice, in order to join those networks of practice that togecher make up the imagned community of the legal professions. In these sessions they enact crossing the boundary from lay person to law student. They try out the new identity as part of a group of neophytes in a place that holds the key cultural markers of the law as practice, the law books: ${ }^{32}$ 
"One day we were sitting in the office of a friend who is a lawyer. Pointing to a collection of volumes on her bookshelf she informed us that this was the 'body of knowledge' of her profession."

After the session with the Law Librarian, the GDL students then have to complete 5 further relatively simple research tasks in their own time that require them to use printed resources, which their academic tutors will discuss with them in their next tutorial.

The difficulty of searching the print resources for a case when you don't know the date; or of following up an entry in a Halsbury's Index when the main volume in question has since been reissued, are amongst the types of research problems looked at during the training. However, the team is under no illusion that the studencs will go on to do all their research in print at the expense of the electronic databases. Indeed, when the students are trained on the electronic resources the following week, there is a collective sigh of relief around the room that there is in fact an easier way to find things. But the real aim of the session is not to convince them that print is better; instead it is firstly to enable them to interact with the printed materials in a way that simply isn't possible with the electronic sources; and secondly to allow them to come face to face with the body of legal knowledge that applies in the community of legal practice that they have now joined.

Printed sources embody physically, and therefore apparently, the size, arrangement, and something of the gravitas of the law. As discussed above the Law Reports bear a mute witness to the persistence through time of legal practice. The monograph collection makes conceptual links topographical through their arrangement, allowing serendipity of discovery of links between subjects, and the possibility of access to sources the students did not know to search for. The sheer size of the Law collection, and specifically the legal encyclopaedias give even the most optimistic speed reader reason to believe that one cannot know all of the law. The need to constantly update and the problem of constant change is brought home in the carrying out of the research exercises. It is these aspects of the experience that are missirg from interaction through a screen alone.

Printed law reports and statutes symbolise the legal profession to the wider world in a way that a screenshot from Westlaw or Lexis cannot do; bound legal volumes give off an aura of law, legal, tawyer; official and authority. Thirk of a TV news item featuring a lawyer; politician or even a senior police officer - more ofter than not the individual is filmed in front of a backdrop of printed law bocks. Why? Because the law books symbolise justice, authority and knowledge, and they reassure the watching audience that the interviewee is a part of that just, authoritative and knowledgeable community of legal practice. By encouraging our students to come into the library and use the physical volumes, we hope to instil in them a deeper understanding of the legal community that they have chosen to be a part of, and of the weight of legal hiscory contained within the Library's law collection.

So, does it work? Feedback on the sessions from the GDL students has been very positive, in particular about the Library and Library staff:

- "I was able to ask lots of basic questions and the library staff didn'c make me feel stupid";

- "l'll be a much more regular library user now, and I know where to go and who to ask if I need help with anything";

- "Picking the law reports up, and flicking through them, helped me to understand the case law system better";

- "Wow! Never realised just how long some cases and acts are!";

- "l'll feel a lot more confident about using the printed resources in future, if I have to".

The GDL students are regularly seen in the Library and most have developed a positive relationship with the Law Librarian. Many of the students continue their studies at NTU on either the Lega! Practice Course or the Bar Professional Training Course, so becoming part of another community of practice, and continue to situate themselves in the Library for their learning.

Although this approach is still quite time intensive for the Law Librarian, for the teaching team involved at NTU the benefits in developing confidence, awareness and relationships far outweigh any perceived disadvantages, and we hope to continue to sicuace their learning in the Library for a long time to come.

\section{CONCLUSION}

Libraries and collections are more than simply information; learning the law is more than memorising information or learning to perform tasks. There is more than knowledge and skills, there is also identity and being part of a community thar itself is part of a network that joins communities of practice, that together make up the imagined community that embodies law and legal practice. ${ }^{33}$ The possibilicies we have tried to describe are easily missed, because it can be hard to see features of the world that are obscured by our dominant metaphors for understanding. However, the practices that take advantage of these aspects of the Library are not inherenty difficult to make happen. We are both located in an educational community of practice. Thus, we have drawr: our example and placed our emphasis on the University Law Library. That does nor mean the learning community approach is imited to Universities; law firms are equally sites of the production of knowledge from a community of practice ${ }^{34}$ and the Library can play more of a role than merely information management here also. 
Many Librarians, academics, practitioners, and students sense that the Law Library is central to the practice of law. It is part of the iconography of law, it is felt to embody the learning that makes the profession learned. We hope to have identified here some of the factors that confirm the validity of these feelings. In a world of scarce resources a case that cannot be articulated is likely to lose by default. The Library is important as a place of books, a place where a lawyer can learn to be.

\section{Footnotes}

'Ludwig Wittgenstein, Tractatus Logico-Philosophicus [6.54].

${ }^{2}$ Michael Polanyi, The Tacit Dimension 2009 University of Chicago Press.

${ }^{3}$ It is congruent with the older and well established "ideas are food" metaphor - by which: "both can be digested, swallowed, devoured, and warmed over, and both can nourish you" George Lakoff and Mark Johnson, Metaphors We Live By, (1980) University of Chicago Press, p. 147. The metaphorical underpinnings of "ideas are food" are: the conduit; ideas are objects; and the mind is a container: and these work with equal naturalness when applied to information.

${ }^{4}$ George Lakoff and Mark Johnson, Metaphors We Live By, (1980) University of Chicago Press, p. 3.

${ }^{5}$ Peter Lyman, The Article 28 Debate and the Sociology of the Information Age (1998) 13 Berkeley Technology Law Journal 1063, pp. 1086-87.

${ }^{6}$ John Seely Brown \& Paul Duguid, The Social Life of Information (2000) Harvard Business School Press, p. 2.

7 Julian Webb, The Body in (E)motion: Thinking through Embodiment in Legal Education, in Affect and Legal Education: Emotion and Learning and Teaching the Law, Paul Maharg and Caroline Maughan (eds) 2011 Ashgate; Peter Jarvis, Learning to be a Person in Society, in Teaching, Learning and Education in Late Modernity: the Selected works of Peter Jarvis 2012 Routledge. Alternatively learning may be understood as a feature of a system, and a person is one type of system, see: Niklas Luhmann, Introduction to Systems Theory, Dirk Baecker (ed) Peter Gilgen (trs) 2013 Polity - but we will ignore this possibility, the individual person as system will be embodied, organisational learning raises complications we do not need to consider here,

a John Clement, Students preconceptions in Introductory Mechanics (1982) 50 (1) American Journal of Physics 66; and, A Conceptual Model discussed by Galileo and used Intuitively by Physics Students in D Gentner \& A Stevens (eds) Mental Models 1983 Erlbaum: Hillsdale, NJ: and discussed in Howard Gardner, The Unschooled Mind: How Children Think and How Schools Should Teach 2004 Basic Books p. 3.

${ }^{9}$ Gardner gives numerous examples in his review of learner misconceptions The Unschooled Mind: How Children Think and How Schools Should Teach 2004 Basic Books pp. 143-181.

${ }^{10}$ John Seely Brown, Allan Collins, and Paul Duguid, Situated Cognition and the Culture of Learning (1989) 18 Educational Researcher 32.

"Situated Learning: Legitimate peripheral participation (1991).

${ }^{12}$ Specifically: midwifes, quartermasters, butchers and nondrinking alcoholics: Jean Lave \& Etienne Wenger, Situated Learning: Legitimate peripheral participation (1991).

${ }^{13}$ There are other legal professions, including some that have traditionally been structured on more of an apprenticeship model, such as legal executives: but for simplicity of exposition we will refer only to solicitors and barristers in the text.

${ }^{14}$ Strictly speaking any of the legal professions will be a network of communities of practice and an imagined community. See: Etienne Wenger-Trayner, Mark Fenton-O'Creevy, Steven Hutchinson, Chris Kubiak, \& Beverly Wenger-Trayner, Learning in Landscapes of Practice: Boundaries, identity, and Knowledgeability in Practice based Learning 2015 Routledge; and Benedict Anderson. We will explore these ideas below. Professional self-regulation and control over entry to the profession seem to be out of fashion in law in much of the common law world.

${ }^{15}$ The occupants of the tailors shops in Happy Corner, Monrovia Liberia, and the researcher as a member of the anthropological and educational research communities in Jean Lave, Apprenticeship in Critical Ethnographic Practice 201I University of Chicago Press; Monrovian tailors, Yucatec midwifes, US Naval quartermasters on an amphibious helicopter transport, butchers in US supermarkets, and nondrinking alcoholics in their alcoholics anonymous meetings, all in Jean Lave \& Etienne Wenger, Situated Learning: Legitimate Peripheral Participation 199/ Cambridge University Press; the health insurance claims processors working in an office together in Etienne Wenger, Communities of Practice: Learning, Meaning and Identity 1999 Cambridge University Press; the team of photocopy service technicians in Julian E Orr, Talking About Machines: An Ethnography of a Modern Job 1996 ILR Press: Ithaca \& London.

:6 Tailors, midwifes, quartermasters, butchers and nondrinking alcohoilics in jean Lave \& Etienne Wenger, Situated Learning: Legitimate Peripheral Participation 1991 Cambridge University Press; health insurance claims processors in Etienne Wenger, Communities of Practice: Learning, Meaning and Identity 1999 Cambridge University Press; service technicians in Julian E Orr. Talking About Machines: An Ethnography of a Modern Job I996 ILR Press: Ithaca \& London.

${ }^{17}$ We will actually use network with a slightly broader meaning - as we will use it to designate a group of communities engaged not just in the same practice but engaged in practices that are connected to that practice. 
${ }^{18}$ Benedict Anderson, Imagined Communities: reflections of the origin and spread of nationalism (revsd ed) Verso2006, loc 206.

${ }^{19}$ Julian E Orr, Talking About Machines, pp. 14-141: "The technicians shape their narratives to create meaning in an inherently ambiguous situation full of facts that do not obviously make sense ... The telling of stories is a situated practice ... the immediacy of context obviously affects their stories." Telling the right story, in the right context, is an important part of competence in a community of practice. And how one talks about matters of concern to the community is also an indicator of membership, and one that outsiders can be introduced to: "Since part of the technicians' mission is teaching the customer how to talk about the machines." Ibid at p. 81 .

${ }^{20}$ Thus, the apprentice tailors learnt to make clothes in reverse order leaving cutting until last ( $L$ \& at p. 72). One important reason for this was that badly performed cutting made cloth useless, a cutting error was expensive: "The apprentice practiced sewing the kind of garment he'd just learned to produce for a while before he undertook the way-in process for cutting it out. The way in for cutting, just like the way in for sewing, required careful observation by the apprentice of many instances of the real thing. But the cost of making an error was usually higher for cutting out a garment than for sewing it together.' Jean Lave, Apprenticeship in Critical Ethnographic Practice at Loc 1066-1068.

${ }^{21}$ The work by Orr on machine technicians led to the creation of the Eureka database which is an example of using information technology to make valuable new learning available to communities of practice through a powerful disseminator of practitioner narratives, see; Seely Brown and Duguid pp. 112-113.

${ }^{22}$ What follows relies heavily on the discussion in Seely Brown \& Duguid pp. 173-205.

${ }^{23}$ [1994] I AC 180 \& 200. Hale DPSC observed a similar relationship with reference to Abbey National Building Society v Cann [199I] I AC 56 and Loyds Bank plc $\vee$ Rosset [1991] I AC 107 in Southern Pacific Mortgages Ltd $\vee$ Scott [2015] AC 385 at [107]: "but that would be very odd as the same appellate committee gave judgment in ... Cann ... on the very same day on which they gave judgment in ... Rosset". Once again these two cases are reported sequentially. However, the internal links are stronger and more legally important in O'Brien and. Pitt.

${ }^{24}$ Simultaneous reading in the vernacular of mass produced books, and newspapers, is identified by Anderson as key catalysts of the imagining of the National community. Benedict Anderson, Imagined Communities: reflections of the origin and spread of nationalism (revised ed) Verso 2006 at loc 942: "These fellow-readers, to whom they were connected through print, formed, in their own secular, particular, visible invisibility, the embryo of the nationally imagined community.".

${ }^{25}$ Occasionally the physical properties record aspects of the history of the book that carry important information, see Seely Brown \& Duguid 2000 pp. 173 174; an example of this is found when the Reports are original - the paper is thinner for the reports published during World War II.

${ }^{26}$ This feeling of connection can be exemplified by collecting of old law documents: "I spent much of my professional life writing opinions. Perhaps for this reason I find the opinions of barristers of an earlier generation particularly interesting." Anthony Taussig, Collecting English Legal manuscripts, 2014, Seldon Society at 11.

${ }^{27}$ Bruno Latour, Visualization and Cognition: Thinking with Eyes and Hands in Knowledge and Society vol 6: Studies in the Sociology of Culture Past and Present, Henrika Kuklick \& Elizabeth Long (eds) 1986 JAl Pess Inc: Greenwich CT, p.I.

${ }^{28}$ Etienne Wenger, Communities of Practice: Learning, Meaning and Identity.

${ }^{29}$ Edwin Hutchins, Cognition in the Wild 1995 MIT.

${ }^{30}$ As Seely Brown \& Duguid remark at 198: "Some documents, such as Web pages, are constantly changing. On the Web it can be very hard to know what the "same document" might mean.".

${ }^{31}$ Studerits certainly act as if they believe that seeming part of the group is an important part of becoming part of the group: Costello CY, Changing Clothes: Gender Inequality and Professional Socialization (2004) 16 National Women's Studies Association journal 138. They literally embody through dress their idea of their new identity. In the sessions they literally enact together being legal researchers, people who can locate and assess the currency of legal texts.

${ }^{32}$ Etienne Wenger-Trayner and Beverly Wenger-Trayner, Learning in a landscape of practice, in Etienne Wenger-Trayner, Mark Fenton-O'Creevy, Steven Hutchinson, Chris Kubiak, \& Beverly Wenger-Trayner, Learning in Landscapes of Practice: Boundaries, identity, and Knowledgeability in Practice based Learning 2015 Routledge, at loc 468.

${ }^{33}$ Although the starting point and terms are different the importance of this aspect of legal education was made in the Carnegie Report under the rubric of the three apprenticeships, it is the third "identity apprenticeship" that we argue Libraries can help with. Sullivan WM, Colby A, Wegner JW, Bond L, \& Shulman LS, Educating Lawyers - Preparation for the Profession of Law, JosseyBass, San Francisco 2007.

${ }^{34}$ See Etienne Wenger, Richard McDermott \& William M Snyder, Cultivating Communities of Practice, Harvard Business School Press 2002 and John Seely Brown \& Paul Duguid, The Social Life of Information (2000) Harvard Business School Press. 


\section{Biographies}

Angela Donaldson has been a professional librarian supporting law students at Nottingham Trent University since 1999. In that time she has worked with law students at all levels from LLB, through LLM, GDL, LPC and BPTC to PhD level. Angela has also been active in BIALL for many years in June 2015 she completed her second stint as Honorary Secretary of the Association.

Graham Ferris is a Reader in Law and has taught law at universities for over twenty years. He has taught and published on property, history and ethics. He has taught undergraduates and postgraduates, and is a member of the Centre of Legal Education at Nottingham Trent Unjversity. 